on dual training is of particular importance. Introduction of dual education in Ukraine is a promising area for the development of higher educational establishments, higher education and technical education. And studying the experience of European countries regarding its organization will help to establish a system of training highly qualified personnel in Ukraine.

The dual form of education is a way of obtaining education that combines education of individuals in education institutions with on-the-job training at enterprises, institutions, organizations on the basis of a contract in order to acquire a certain qualification. It is the dreamy format of modern youth. Even within the walls of the education institutions, the educators have the optimum opportunity to gain some independence, to have a monetary remuneration for their work, and to adapt to adult life and professional conditions less problematic.

Key words dual form of education, educational establishment, vocational training, professional activity, professional socialization, human resources potential.

Удк 378.1:355.232.2

Роман Невзоров

Харківський національний університет Повітряних Сил імені Івана Кожедуба

ORCID ID 0000-0003-1496-2465

DOI 10.24139/2312-5993/2020.01/248-256

\title{
НАЗЕМНЕ НАВЧАННЯ БОЙОВИМ ПОЛЬОТАМ ЯК УМОВА ЯКІСНОЇ ФАХОВОЇ ПІДГОТОВКИ МАЙБУТНІХ ЛЬОТЧИКІВ ТАКТИЧНОЇ АВІАЦІї
}

Автором досліджено сучасні погляди на проблему наземного навчання бойовим польотам майбутніх льотчиків тактичної авіачії. Визначено завдання, психолого-педагогічні закономірності наземного навчання бойовим польотам та основні бойові якості майбутнього льотчика тактичної авіачії. Наземне навчання бойовим польотам схарактеризовано як самостійний напрям військової педагогіки. Обгрунтовано педагогічну систему «наземної бойової підготовки майбутніх льотчиків тактичної авіації».

Ключові слова: майбутній льотчик тактичної авіачії, навчання бойовим польотам, психолого-педагогічні закономірності, педагогічна система, прийоми навчання, зміст навчання.

Постановка проблеми. Одним 3 основних завдань освітнього процесу льотного закладу вищої військової освіти (ЛЗВВО) є формування в майбутніх льотчиків знань, умінь, навичок виконання бойових завдань. Зростання обсягів науково-технічної інформації, інтенсивне впровадження в бойове застосування авіації досягнень науки й техніки, розвиток тактичних прийомів і способів бойового застосування підрозділів авіації обумовили необхідність глибокого засвоєння великого обсягу знань із тактики авіації, набуття навичок із підготовки й виконання бойових польотів. Таким чином, постійний розвиток прийомів і способів збройної боротьби вимагає набуття майбутніми льотчиками тактичної авіації навичок самовдосконалення, що, у свою чергу, обумовлює необхідність адекватних змін у сфері навчання виконанню бойових польотів. 
Характер дій екіпажів, підрозділів і частин авіації в сучасному бою вимагає від майбутніх військових льотчиків тактичної авіації високого рівня розвитку розумових здібностей, тактичного мислення, вміння міцно засвоювати нові знання, здатності правильно орієнтуватись у швидкоплинній повітряній обстановці, аналізувати різноманітну й велику за обсягом тактичну інформацію, швидкого прийняття оптимальних рішень під час бойового польоту. Реалізація цих вимог можлива лише за умови забезпечення активізації розумової діяльності майбутніх військових льотчиків на всіх етапах їх професійної підготовки за результатами застосування відповідних форм, методів і прийомів навчання. Тому навчання бойовим польотам повинно забезпечити вирішення таких основних складних завдань: фундаменталізація теоретичної підготовки зі спеціальних і тактичних дисциплін; інтенсифікація навчання на всіх видах занять із тактичних і спеціальних дисциплін; формування творчого гнучкого тактичного мислення, стійкості до впливу чинників бойового польоту, образності мислення в бойовому польоті, фізичної витривалості; виховання установки на перемогу, ініціативності, воєнної хитрості; розробка й упровадження нових форм і способів бойового застосування підрозділів авіації, тактичних прийомів і бойових маневрів; пошук і впровадження нових форм і методів навчання (Квятош, 2010).

Вищезазначене обумовлює необхідність формування не лише особистісних якостей майбутнього льотчика тактичної авіації, але й удосконалення освітнього процесу в цілому щодо навчання бойовим польотам.

Аналіз актуальних досліджень. Над проблемою успішності навчання майбутніх військових льотчиків працюють учені різних напрямів: психологи, фізіологи, інженери, авіаційні лікарі, методисти льотного навчання, фахівці фізичної підготовки та ін. Серед психолого-педагогічних досліджень, що направленні на проблему підготовки авіаційних фахівців, назвемо такі: Т. Плачинда (Плачинда, 2014) розробила теоретичні й методичні засади забезпечення якості професійної підготовки курсантів льотних навчальних закладів; О. Керницький (Керницький, 2015) розглядав процес формування готовності курсантів льотних навчальних закладів до професійної діяльності; П. Онипченком (Онипченко, 2004) проведено аналіз професійно-педагогічної підготовки льотно-інструкторського складу лЗВВО; Д. Приходько (Приходько, 2005) працював над особливостями станів психічного напруження курсантівльотчиків у період наземної підготовки. Проте можна зазначити, що ефективність підготовки військових льотчиків багато в чому залежить від того, наскільки в освітньому процесі ЛЗВВО, зокрема його змісті, розуміються та використовуються психолого-педагогічні умови підготовки майбутніх льотчиків тактичної авіації до виконання бойових польотів.

Викладене вище дозволило визначити мету статті - обґрунтування необхідності впровадження наземного навчання бойовим польотам 
майбутніх льотчиків тактичної авіації як окремого напряму професійної підготовки означених фахівців.

Для реалізації мети було використано загальнонаукові методи дослідження (аналіз, синтез, зіставлення, узагальнення, систематизація) для вивчення наукових джерел із професійної підготовки майбутніх військових льотчиків і визначення напрямів удосконалення наземного навчання бойовим польотам.

Виклад основного матеріалу. Основним завданням наземного навчання бойовим польотам майбутніх льотчиків тактичної авіації, на нашу думку, $€$ формування навичок визначення (розробки) й застосування сукупності принципів, способів організації, побудови та здійснення теоретичної та практичної діяльності щодо підготовки й ведення протиборства бойових авіаційних комплексів з урахуванням оновлення технологій бойового застосування авіації. 3 урахуванням визначеного завдання процес наземного навчання доцільно побудувати з урахуванням таких психолого-педагогічних закономірностей:

- недоліки в навчанні змісту й порядку підготовки до бойових польотів (навчання моделюванню та плануванню бойових польотів) у реальних бойових умовах складно компенсувати досконалістю навченості виконанню стандартних тактичних прийомів і бойових маневрів;

- у процесі навчання порядку підготовки до виконання бойових польотів доцільно навчити майбутніх льотчиків визначати такі закономірності: відповідності наявних сил і засобів меті бойового польоту та поставленому бойовому завданню; відповідності можливостей комплексу авіаційного озброєння умовам виконання бойового польоту; зосередження зусиль проти уразливих елементів (дій, напрямів, об'єктів тощо) противника; залежності ефективності виконання бойового завдання від постійної дезінформації (приховування, введення в оману) противника щодо задуму бойового польоту й тактичних прийомів (бойових маневрів) застосування авіаційних засобів ураження;

- навчання майбутніх льотчиків розробці й застосуванню стратагем (планів) бойових польотів забезпечує формування навичок упередження противника в застосуванні засобів ураження;

- формування навичок постійного (від зльоту до посадки) пошуку в повітряному просторі тактично вигідних положень відносно елементів бойового авіаційного комплексу противника;

- інтенсивне бойове маневрування вимагає формування переносимості великих перевантажень, стійкості просторового орієнтування відносно засобів повітряного й наземного противника, випереджального оперативного тактичного мислення в умовах дефіциту часу;

- формування мотиваційно-вольових якостей: мотивація на агресивне захоплення й утримання тактичної переваги в бойових польотах, 
мотивація на одержання перемоги, управління собою та мобілізація сил у бойовому польоті, самоконтроль, самооцінка готовності до виконання бойового польоту.

Таким чином, навчання бойовим польотам в умовах сучасного темпу розвитку авіаційної техніки буде результативним, коли воно буде здійснюватися відповідно до обґрунтованих психолого-педагогічних закономірностей з урахуванням сучасного стану й перспектив розвитку бойового застосування авіації.

Спираючись на постулати концепції людського фактору, що обґрунтовані науковцями (Байнетов, 2010), можна визначити чотири основні бойові якості майбутнього військового льотчика, які необхідно розвивати в процесі наземного навчання бойовим польотам: потреби й мотиви; професійна підготовленість до виконання бойових польотів; працездатність в умовах бойових польотів і функціональні резерви; професійно важливі якості. Визначені якості повинні бути спрямовані на формування системи знань, умінь і навичок нейтралізації переваг противника та максимальної реалізації власних бойових можливостей у конкретних умовах повітряно-тактичної обстановки.

Тому вважаємо за доцільне виокремити наземне навчання бойовим польотам майбутніх військових льотчиків тактичної авіації (наземну бойову підготовку майбутніх льотчиків тактичної авіації) як самостійний напрям військової педагогіки та досліджувати особливості навчання професійній діяльності військового льотчика на різних етапах підготовки й виконання бойових польотів.

Характерною ознакою наземного навчання бойовим польотам як окремого напряму військової педагогіки $€$ особливо чіткий прояв наукової теорії в навчанні мистецтву підготовки й виконання бойових польотів. Тому «наземна бойова підготовка майбутніх льотчиків тактичної авіації», як окремий напрям наукової теорії, повинна використовувати результати й узагальнення професійної педагогіки й синтезувати та спиратися на теоретичні ідеї інших наук про людину.

Предметом наземного навчання бойовим польотам майбутніх льотчиків тактичної авіації $€$ процес формування на землі особистості майбутнього льотчика тактичної авіації здатного до ефективної бойової діяльності в повітрі.

Об'єктом наземного навчання бойовим польотам $€$ особистість майбутнього льотчика тактичної авіації, яка формується та розвивається на землі відповідно до вимог і умов бойових польотів.

Відповідно до основних ознак військово-педагогічної науки наземне навчання бойовим польотам здійснює вивчення таких теоретичних проблем:

- виявлення закономірностей розвитку й формування особистості майбутнього льотчика тактичної авіації в умовах спеціально організованого наземного виховання та навчання бойовим польотам; 
- визначення або уточнення задач наземного навчання бойовим польотам;

- удосконалення змісту наземного виховання та навчання бойовим польотам;

- розвиток методології наземного навчання бойовим польотам.

Виходячи з цього, поняття наземного навчання бойовим польотам (наземної бойової підготовки) майбутніх льотчиків тактичної авіації може бути сформульоване таким чином: наземне навчання бойовим польотам (наземна бойова підготовка) майбутніх льотчиків тактичної авіації - напрям військово-педагогічної науки, що вивчає закономірності формування на землі особистості, бойова діяльність якої здійснюється в повітрі, та дає обґрунтування змісту, формам і методам системи наземного виховання, навчання та взагалі освіти майбутніх льотчиків тактичної авіації.

Протягом останнього століття питання обґрунтування системи професійної підготовки льотного складу досліджували передусім психологічна й медична науки, а також у сфері підготовки військових льотчиків - військова педагогіка, у сфері підготовки цивільних льотчиків -професійна педагогіка. Історія розвитку теорії професійної підготовки льотного складу має велику кількість прикладів, коли здійснювалися спроби систематизувати науковий напрям, що лежить в основі теорії навчання льотчиків. До найбільш близьких до рішення даної проблеми, можна віднести розробку психологопедагогічної теорії льотного навчання, поняття якої ототожнювалося з поняттям «авіаційна психологія та педагогіка». Але при цьому не вирішувалася задача наземного навчання майбутніх льотчиків тактичної авіації мистецтву підготовки й виконання бойових польотів. Підготовка здійснювалася на основі «методики льотного навчання», що включала основні положення «авіаційної психології та педагогіки», як складової частини.

Тому вважаємо за доцільне розробити педагогічну систему наземної бойової підготовки майбутніх льотчиків тактичної авіації, що як прикладний аспект включає в себе практичну діяльність із наземного виховання майбутнього бойового льотчика: систему знань, умінь, навичок і здібностей підготовки та виконання бойових польотів.

Основними елементами системи наземної бойової підготовки майбутніх льотчиків тактичної авіації можна вважати тренажерну, фізичну, теоретичну та психологічну підготовку (Байнетов, 2010).

Р. Макаров вважає, що під структурою педагогічної системи професійної підготовки льотчиків слід розуміти спеціальну цілеспрямовану просторово-часову інтеграцію елементів підготовки в інтересах отримання системою запрограмованого педагогічного результату (Макаров, 2000). Таким чином, педагогічна система наземної бойової підготовки майбутніх льотчиків тактичної авіації забезпечує інтеграцію процесів теоретичної, фізичної, психологічної, тренажерної 
підготовки та фокусує часткові педагогічні процеси на досягнення мети забезпечення якості наземного навчання бойовим польотам майбутніх льотчиків тактичної авіації.

Відтак, метою педагогічної системи наземної бойової підготовки майбутніх льотчиків тактичної авіації $\epsilon$ розвиток теорії навчання й виховання щодо організації та здійснення цілеспрямованої якісної підготовки до бойової діяльності з урахуванням існуючої специфіки (умов і вимог) бойового застосування підрозділів тактичної авіації.

Ураховуючи вищезазначену мету педагогічної системи наземної бойової підготовки майбутніх льотчиків тактичної авіації можна визначити такі основні ії складники:

- загальна система наземного навчання бойовим польотам;

- система теоретичного навчання бойовим польотам;

- системи наземного практичного навчання бойовим польотам;

- методики наземного навчання бойовим польотам;

- системи засобів наземного навчання бойовим польотам;

- системи підготовки викладацького складу та інструкторів авіаційних тренажерів.

Характерною ознакою педагогічної системи наземної бойової підготовки майбутніх льотчиків тактичної авіації $\epsilon$ наявність таких специфічних форм педагогічного процесу (Байнетов, 2010):

- підготовка до бойових дій до отримання бойового завдання;

- підготовка до бойових дій після отримання бойового завдання;

- контроль готовності до виконання бойового польоту;

- відпрацювання бойових польотів на авіаційних тренажерах, імітаційних засобах;

- розбір бойових польотів;

- підготовка до наступного бойового вильоту.

Педагогічний процес наземного навчання бойовим польотам майбутніх льотчиків тактичної авіації пов'язаний з умовами бойової діяльності льотчика в системі «льотчик $\rightarrow$ бойовий авіаційний комплекс $\rightarrow$ бойові завдання», що визначає основні особливості прийомів та змісту наземного навчання бойовим польотам (Байнетов, 2010), а саме:

- зміст навчання нерозривно пов'язаний із сучасними умовами виконання бойових польотів і діяльністю льотчика в процесі підготовки й виконання різних видів бойових польотів;

- прийоми навчання залежать від тактичних прийомів, бойових маневрів, форм, способів, умов підготовки та бойового застосування авіації;

- прийоми навчання враховують вплив на тих, хто навчається, стресових ситуацій бойового польоту; 
- прийоми навчання включають штучне створення стресових ситуацій умов підготовки й виконання бойових польотів із метою навчання визначенню способів виходу з них;

- прийоми навчання враховують наявність жорстких обмежень по відхиленням від вимог безпеки польотів.

Таким чином, основними особливостями дослідження закономірностей функціонування «системи наземної бойової підготовки майбутніх льотчиків тактичної авіації», що проводяться з використанням системного підходу, є (Ягупов 2002, 2012):

- система наземної бойової підготовки майбутніх льотчиків тактичної авіації, як предмет дослідження, розглядається цілісною структурою, яка складається з відносно окремих елементів (підсистем) - етапів (розділів) підготовки, кожен з яких, у свою чергу, сам може бути системою;

- єдність елементів системи - етапів (розділів) підготовки досягається визначеними зв'язками й відносинами між ними, що надає визначені властивості всій системі, що не є простою сумою властивостей їі елементів;

- елементи системи - етапи (розділи) підготовки - здійснюють взаємний вплив один на одного.

Висновки. Отже, на основі вищевикладеного можна зробити такі висновки:

1. Протиріччя між високими вимогами підготовленості льотчиків тактичної авіації до виконання бойових завдань та існуючим станом навчання бойовим польотам майбутніх льотчиків тактичної авіації можуть бути вирішені шляхом надання педагогічному процесу наземного навчання бойовим польотам статусу напряму військово-педагогічної науки.

2. Наземне навчання бойовим польотам майбутніх льотчиків тактичної авіації - напрям військово-педагогічної науки, що вивчає закономірності формування на землі особистості, бойова діяльність якої здійснюється в повітрі, та дає обґрунтування змісту, формам і методам навчання, виховання й освіти майбутніх льотчиків тактичної авіації.

Перспективою подальших наукових розвідок вбачаємо аналіз змісту діяльності військового льотчика в процесі підготовки й виконання різних видів бойових польотів.

\section{ЛІТЕРАТУРА}

Байнетов, С. (ред.) (2010). Хрестоматия человеческого фактора в авиации через призму безопасности полётов (круг чтения). Москва: МАКЧАК (Bainetov, S. (ed) (2010) The anthology of the human factor in aviation through the prism of flight safety (a circle of reading). M oscow: M AKCHAK).

Квятош, Е. (2010). Развитие интеллектуальных способностей на основе информационных технологий в профессиональной подготовке военного летчика (автореф. дис. ... канд. пед. наук: 13.00.08). Краснодар (Kviatosh E. (2010) The development of intellectual abilities based on information technology in the professional training of a military pilot (PhD thesis abstract). Krasnodar). 
Керницький, О. (2015). Формування готовності курсантів льотних навчальних закладів до професійної діяльності. Педагогіка формування творчої особистості у вищій і загальноосвітній школах, 41 (94), 155-162 (Kernytskyi, 0. (2015). Formation of readiness of cadets of flight educational institutions for professional activity. Pedagogy of creative personality formation in higher and general academic schools, 41 (94), 155-162).

Макаров, Р. (2000). Психологические основы дидактики лётного обучения. Москва: МАКЧАК, ГЛАУ (Makarov, R. (2000). Psychological bases of didactics of flight training. Moscow: MAKCHAK, GLAU).

Онипченко, П. (2004). Професійно-педагогічна підготовка льотно-інструкторського складу ВПС України у вищих навчальних військових закладах (дис. ... канд. пед. наук: 13.00.04). Луганськ (Onipchenko, Р. (2004). Professional-pedagogical training of the flight-training personnel of the Air Force of Ukraine in higher education military establishments (PhD thesis). Luhansk).

Плачинда, Т. (2014). Профресійна підготовка майбутніх авіаційних фахівців: зарубіжний і вітчизняний досвід та шляхи підвищення якості: монографія. Кіровоград: Полімед-Сервіс (Plachynda, Т. (2014). Professional training of future aviation specialists: foreign and domestic experience and ways to improve quality: monograph. Kirovohrad: Polimed-Servis).

Приходько, Д. (2005). Актуальні проблеми моделювання напружених психічних станів курсантів-льотчиків у період наземної підготовки. Війна й насильство: минуле та майбутнє: матеріали наук.-практ. конф., присвяч. 60-річчю перемоги у Великій Вітчизняній війні (Харків, 25 квіт. 2005 р.). Харків: АЦзУ, 53-54. (Prykhodko, D. (2005). Current problems of modeling of tension mental states of cadets-pilots in the period of ground training. War and violence: past and future: materials of scientific-practical. conf., dedicated 60th Anniversary of Victory in the Great Patriotic War (Kharkiv, April 25, 2005).

Ягупов, В. (2002). Педагогіка. Київ: Либідь (Yahupov, V. (2002). Pedagogy. Kyiv: Lybid).

Ягупов, В. (2012). Провідні методологічні характеристики основних видів компетентності майбутніх фахівців, що формуються в системі професійно-технічної освіти. Модернізація професійної освіти і навчання, 2, 45-59 (Yahupov, V. (2012). Leading methodological characteristics of the main types of competencies of future specialists formed in the system of vocational-technical education. Modernization of vocational education and training: collection of research papers, 2, 45-59).

\section{PEЗЮME}

Невзоров Роман. Наземное обучение боевым полётам как условие качественной профессиональной подготовки будущих лётчиков тактической авиации.

Автором исследованы современные взгляды на проблему наземного обучения боевым полётам будущих лётчиков тактической авиации. Определены задачи, психолого-педагогические закономерности наземного обучения боевым полётам, а также основные боевые качества будущего лётчика тактической авиации. Наземное обучение боевым полётам охарактеризовано как самостоятельное направление военной педагогики. Обоснована педагогическая система «наземной боевой подготовки будущих лётчиков тактической авиации».

Ключевые слова: будущий лётчик тактической авиации, обучение боевым полётам, психолого-педагогические закономерности, педагогчческая система, приёмы обучения, содержание обучения. 


\section{SUM MARY}

Nevzorov Roman. Ground combat flight training as a condition of qualitative professional training for future tactical aviation pilots.

The constant development of techniques and methods of armed struggle necessitates activation, according to the results of the use of appropriate forms, methods, and techniques of training, the mental activity of military pilots at all stages of their professional training.

The aim of the article is the rationale of the need for introduction of ground combat flight training of future tactical aviation pilots as a separate line of professional training of the designated specialists.

The methods of research: general scientific (analysis, synthesis, comparison, generalization, systematization) were used to study scientific sources for the training of future military pilots and to identify areas for improving ground combat flight training.

Research results. Pedagogical system of ground combat training of future tactical aviation pilots contains the following components: a general system for ground combat flight training; a system of theoretical combat flight training; a systems of practical ground combat flight training; methods of ground combat flight training; a system of tools of ground combat flight training; a system of training of teaching and instructional staff of aviation simulators.

A characteristic feature of the pedagogical system of ground combat training of future tactical aviation pilots is presence of the following specific forms of the pedagogical process: preparation for combat operation before getting combat missions; preparation for combat operation after getting combat missions; examination of readiness for combat flight operation; practicing of combat flights on aviation simulators and modelling devices; analysis of combat flights; preparation for the next combat flight.

Conclusions. The contradictions between the high requirements for preparedness of tactical aviation pilots to perform combat missions and the current condition of training for combat flights of future tactical aviation pilots can be solved by giving the pedagogical process of ground combat flight training the status of discipline of military-pedagogical science.

Key words future tactical aviation pilot, training for combat flights, psychological and pedagogical patterns, pedagogical system, training techniques, content of training.

Удк 613:378.016

Тетяна Парфіненко

Харківський національний університет імені В. Н. Каразіна ORCID ID 0000-0001-7442-9027

DOI 10.24139/2312-5993/2020.01/256-266

\section{ВИЗНАЧЕННЯ РІВНІВ СФОРМОВАННОСТІ ЗДОРОВОГО СТИЛЮ ЖИТТЯ СТУДЕНТІВ У ПРОЦЕСІ НАВЧАННЯ ОСНОВ ЗДОРОВ'Я}

Метою даної статmі є визначення рівнів сформованості здорового стилю життя студентів факультету комп'ютерних наук Харківського національного університету імені В. Н. Каразіна у прочесі навчання основ здоров'я. Для досягнення поставленої мети використовувалися такі методи дослідження: теоретичного аналізу й узагальнення науково-педагогічної літератури, анкетування, тестування, педагогічний експеримент.

У статті наведено результати експериментальної перевірки методики формування здорового стилю життя студентів у прочесі навчання основ здоров'я. У 